\title{
Association between caries status and quality of life of adults in Pinrang, 2019
}

\author{
Rasmidar Samad*
}

\section{Abstract}

Objective: To analyze association between caries status and quality of life of adult in Pinrang, 2019; promoting epidemiology data in planning and evaluation of oral health care programs. Material and Methods: This study used pilot pathfinder design. The subject consist of 345 subjects aged $\geq 18$ years old and randomly selected from urban and rural areas in Pinrang, Indonesia. The data were collected by 194 subject from urban area and 151 subject from rural areas. We used DMF-T index according to WHO methodology and Oral Health Impact Profile (OHIP-14) questionnaire translated to language (Indonesia version).

Results: Based on gender, DMF-T index of males was lower than females in urban areas, whereas DMF-T index of males was higher than women in rural areas. In urban and rural areas, the mean of $F$ (filled) component was 0.00 . The highest DMF-T index was at subjects aged $>60$ years, 17.19 in urban areas and 16.52 in rural areas, respectively.

Conclusion: There was no significant association between caries status aged 18-44 years and quality of life in urban and rural areas. In adults aged $\geq 45$ years, the results showed that there was no significant association between caries status and quality of life of adults in rural areas and a significant association between caries status and the quality of life of adults in urban areas.
Department of Dental Public Health, Faculty of Dentistry, Hasanuddin University, Makassar, Indonesia
*Corresponding to: Rasmidar Samad, Department of Dental Public Health, Faculty of Dentistry, Hasanuddin University, Makassar, Indonesia mellindaleonarto27@gmail.com

Received: 12 February 2019

Revised: 10 July 2019

Accepted: 30 July 2019

Available Online 1 August 2019

Keywords: Adults, DMF-T, Epidemiology, OHIP-14

Cite this Article: Samad R. 2019. Association between caries status and quality of life of adults in Pinrang, 2019. Journal of Dentomaxillofacial Science. 4(2): 100-104. DOI: 10.15562/ jdmfs.v4i2.938

\section{Introduction}

Oral health is the main component of individuals' general health and it allows individuals to run their daily activities (mastication, articulation, socializing) without any illness, discomfort, and disability. ${ }^{1}$ The World Health Organization (WHO) states "Health is a state complete physical, mental, and social wellbeing and not merely the absence of disease and infirmity. ${ }^{2,3}$ Thereby quality of life (QoL) of a patient is taken into account. ${ }^{3}$ QoL measures are of importance in order to look further than just the presence of health or disease and into the way that impacts on his daily performance. ${ }^{4}$ The key to improve QoL is by repatriating oral function, mastication, preventing oral disease, repairing oral tissue, and tackling the patient's complaints. ${ }^{1}$

Oral health-related quality of life (OHRQoL) is defined as a multidimensional construct that reflects (among other things) people's comfort when eating, sleeping, and engaging in social interaction; their self-esteem; and their satisfaction with respect to their oral health. ${ }^{2-4}$ The OHRQoL is usually assessed by studying how factors such as function, pain, psychological, and social aspects affect the well-being an individual. ${ }^{2-6}$

The oral health status can in turn be affected by many personal, social, and local factors. Differences in the oral health status can indeed be seen when comparing differing regions within a country or between countries and geographic locations. ${ }^{4}$ Dental caries and periodontal disease are the most common oral diseases affecting millions people worldwide. ${ }^{3,5}$ Approximately 2.3 billion (32\%) people have dental caries in their permanent tooth worldwide. Indonesia Basic Health Research (Riskesdas) 2013 reported that the prevalence of dental caries in Indonesia increased up to $53.2 \%$ in 2013 from $43.4 \%$ in $2007 . .^{3,7}$ Indonesia's DMF-T index is 4.6 which means that there are 460 decay teeth per 100 people. ${ }^{7,8}$ The number also represents that there are approximately 5 decay teeth in each individual. ${ }^{8}$

Pinrang is one of the regency in Sulawesi Province, located approximately $185 \mathrm{~km}$ north of Makassar City. The administrative area of Pinrang divided into 12 districs and 108 villages/ sub-districts (69 sub-districts and 39 villages) with an area of $1.961 .77 \mathrm{~km}^{2}$. The area of Mattiro Bulu Subdistrict is 132.49 with a percentage of $6.75 \%$ of the total area of Pinrang Regency, the area of Watang Sawitto District is 58.97 with a percentage of $3.01 \%$ of the total area of Pinrang Regency, and the area of Suppa District is 74.2 with a percentage $3.78 \%$. According to data from the Pinrang Regency Central Bureau of Statistics in 2017, the population of Pinrang Regency in 2016 was 369.595 people, with a population density of 188.4 people $/ \mathrm{km}^{2}$. The largest population is in Watang Sawitto District, which is 55.571 people. In rural areas, the population of Mattiro Bulu Subdistrict is 28.053 people and the number 
Table 1 Subject distribution according to sociodemographic characteristics as well as mean value of DMF-T and OHI-P

\begin{tabular}{|c|c|c|c|c|c|c|c|c|c|c|c|c|c|c|c|}
\hline \multirow{2}{*}{\multicolumn{2}{|c|}{$\begin{array}{l}\text { Characteristic } \\
\text { Age/Gender }\end{array}$}} & \multicolumn{7}{|c|}{ Urban } & \multicolumn{7}{|c|}{ Rural } \\
\hline & & \multirow{2}{*}{$\begin{array}{c}\mathrm{D} \\
1.55\end{array}$} & \multirow{2}{*}{$\frac{\mathrm{M}}{2.27}$} & \multirow{2}{*}{$\frac{F}{0.00}$} & \multirow{2}{*}{$\frac{\text { DMFT }}{3.82}$} & \multirow{2}{*}{$\begin{array}{c}\text { Status } \\
\text { very low }\end{array}$} & \multirow{2}{*}{$\begin{array}{l}\text { OHIP } \\
13.99\end{array}$} & \multirow{2}{*}{$\frac{\text { Category }}{\text { good }}$} & \multirow{2}{*}{$\frac{\mathrm{D}}{1.34}$} & \multirow{2}{*}{$\frac{M}{3.00}$} & \multirow{2}{*}{$\frac{F}{0.00}$} & \multirow{2}{*}{$\frac{\text { DMFT }}{4.34}$} & \multirow{2}{*}{$\begin{array}{c}\text { Status } \\
\text { very low }\end{array}$} & \multirow{2}{*}{$\frac{\text { OHIP }}{19.88}$} & \multirow{2}{*}{$\frac{\text { Category }}{\text { good }}$} \\
\hline $18-44$ & mean & & & & & & & & & & & & & & \\
\hline years old & SD & 1.77 & 3.62 & 0.00 & 4.29 & very low & 10.83 & good & 1.76 & 4.59 & 0.00 & 5.05 & very low & 14.17 & good \\
\hline $45-60$ & mean & 1.37 & 6.63 & 0.00 & 8.00 & low & 20.51 & good & 1.16 & 8.23 & 0.00 & 9.39 & moderate & 18.61 & good \\
\hline years old & SD & 1.75 & 8.18 & 0.00 & 8.30 & low & 13.66 & good & 1.68 & 9.68 & 0.00 & 9.63 & moderate & 13.02 & good \\
\hline$>60$ & mean & 0.44 & 16.75 & 0.00 & 17.19 & high & 21.50 & good & 0.36 & 16.16 & 0.00 & 16.52 & high & 22.16 & good \\
\hline years old & SD & 1.09 & 11.70 & 0.00 & 11.08 & high & 11.29 & good & 0.91 & 14.54 & 0.00 & 14.43 & high & 15.39 & good \\
\hline \multirow[t]{2}{*}{ Male } & mean & 1.25 & 4.77 & 0.00 & 6.02 & very low & 15.05 & good & 0.53 & 10.30 & 0.00 & 10.83 & very low & 15.27 & good \\
\hline & SD & 1.95 & 7.74 & 0.00 & 8.02 & very low & 13.24 & good & 1.11 & 12.65 & 0.00 & 12.58 & very low & 14.08 & good \\
\hline \multirow[t]{2}{*}{ Female } & mean & 1.47 & 5.00 & 0.00 & 6.47 & moderate & 17.59 & good & 1.27 & 5.81 & 0.00 & 7.08 & very low & 21.03 & good \\
\hline & SD & 1.64 & 7.50 & 0.00 & 7.40 & moderate & 11.79 & good & 1.74 & 8.73 & 0.00 & 8.71 & very low & 13.81 & good \\
\hline
\end{tabular}

Table 2 Frequency of responses to items in the OHIP-14 in the study sample

\begin{tabular}{|c|c|c|c|c|c|c|c|c|c|c|c|}
\hline \multirow{2}{*}{ Dimension } & \multirow{2}{*}{ Item } & \multicolumn{2}{|c|}{ Never (score 0) } & \multicolumn{2}{|c|}{ Hardly ever (score 1 ) } & \multicolumn{2}{|c|}{ Occasionally (score 2) } & \multicolumn{2}{|c|}{ Fairly often (score 3) } & \multicolumn{2}{|c|}{ Very often (score 4 ) } \\
\hline & & $\mathrm{N}$ & $\%$ & $\mathrm{~N}$ & $\%$ & $\mathrm{~N}$ & $\%$ & $\mathrm{~N}$ & $\%$ & $\mathrm{~N}$ & $\%$ \\
\hline Funtional & Trouble pronouncing word & 177 & 51.3 & 3 & 15.4 & 60 & 17.4 & 1 & 14.8 & 4 & 1.2 \\
\hline Limitations & Worsened sense of taste & 145 & 42.0 & 6 & 22.0 & 67 & 19.4 & 4 & 15.7 & 3 & 0.9 \\
\hline \multirow{6}{*}{$\begin{array}{l}\text { Psychological } \\
\text { pain } \\
\text { Physical } \\
\text { disability } \\
\text { Social disability }\end{array}$} & Painful aching in mouth & 79 & 22.9 & 8 & 25.5 & 114 & 33.0 & 3 & 18.3 & 1 & 0.3 \\
\hline & Uncomfortable to eat food & 85 & 24.6 & 7 & 22.3 & 107 & 31.0 & 3 & 21.2 & 3 & 0.9 \\
\hline & Being self-conscious & 104 & 30.1 & 4 & 18.6 & 104 & 30.1 & 0 & 20.3 & 3 & 0.9 \\
\hline & Feeling tense & 131 & 38.0 & 4 & 18.6 & 98 & 28.4 & 8 & 13.9 & 4 & 1.2 \\
\hline & Unsatisfactory diet & 93 & 27.0 & 6 & 19.1 & 113 & 32.8 & 8 & 19.7 & 5 & 1.4 \\
\hline & Interrupting meals & 106 & 30.7 & 6 & 22.0 & 98 & 28.4 & 0 & 17.4 & 5 & 1.4 \\
\hline \multirow{4}{*}{$\begin{array}{l}\text { Psychological } \\
\text { disability } \\
\text { Social disability }\end{array}$} & Difficulty relaxing & 120 & 34.8 & 8 & 22.6 & 92 & 26.7 & 1 & 14.8 & 4 & 1.2 \\
\hline & Embrassed & 113 & 32.8 & 8 & 13.9 & 108 & 31.3 & 2 & 20.9 & 4 & 1.2 \\
\hline & Irritablewith other people & 133 & 38.6 & 6 & 24.9 & 76 & 22.0 & 4 & 12.8 & 6 & 1.7 \\
\hline & Difficulty doing usual jobs & 113 & 32.8 & 2 & 26.7 & 89 & 25.8 & 9 & 14.2 & 2 & 0.6 \\
\hline \multirow[t]{2}{*}{ Handicap } & Life less satisfying & 127 & 36.8 & 8 & 22.6 & 81 & 23.5 & 7 & 16.5 & 2 & 0.6 \\
\hline & Unable to funtion & 118 & 34.2 & 2 & 23.8 & 85 & 24.6 & 5 & 15.9 & 5 & 1.4 \\
\hline
\end{tabular}

of Suppa Districts is 31.929 people. ${ }^{9}$

In 2016, health facilities in Pinrang District are 3 hospitals, 16 health centers, and 369 posyandu. The medical personnels are 12 specialist doctors, 43 general practitioners, 20 dentists, 25 pharmacies, 266 nurses, and 153 midwives. In urban areas, Watang Sawitto sub-district, there are 3 hospitals, 1 health center, and 36 posyandu. In rural areas, Mattiro Bulu sub-district, there are 1 Puskesmas and 30 Posyandu, in Suppa District, there are 2 health centers and 34 posyandu. ${ }^{9}$ The number of health workers registered in 2016 in Watang Sawitto District are 22 medical personnels, while in rural areas, Mattiro Bulu subdistrict there are 4 medical personnel and in Suppa sub-district there are 5 medical personnel. ${ }^{6}$ From these data, it can be seen that there uneven facilities distribution, infrastructure, and health personnel in these sub-districts.

Health facilities and infrastructure play role in improving oral health. Lack of health facilities and infrastructure causes uneven distribution of health services, so that it will affect the quality of life in an area. From the review of the situation abovementioned and the absence of data regarding the state of caries status on the quality of life related to the oral cavity in this area, the authors are interested in knowing the association of caries status and quality of life related to the oral cavity in the adult community of Pinrang Regency, especially in Watang Sawitto Sub-district, Mattiro Bulu sub-district, and Suppa sub-district.

\section{Material and Methods}

This study was approved by Ethics Committee of Dentistry Faculty, Hasanuddin University with serial number 0136/PL09/KEPK FKG-RSGM UNHAS/ 2019. All participants signed the informed consent before participating in any part of the research. Number 0136/PL09/KEPK FKG-RSGM UNHAS 2019. All participants signed the informed consent before participating in any part of the research. 
Table 3 Subject distribution based on quality of life status

\begin{tabular}{|c|c|c|c|c|c|}
\hline \multirow{2}{*}{\multicolumn{2}{|c|}{ Variable }} & & \multicolumn{2}{|c|}{ Location } & \multirow{2}{*}{ Total } \\
\hline & & & Urban & Rural & \\
\hline \multirow{6}{*}{ OHIP-14 } & good & $\mathrm{n}$ & 117 & 69 & 186 \\
\hline & & $\%$ & 60.3 & 45.7 & 53.9 \\
\hline & moderate & $\mathrm{n}$ & 63 & 55 & 118 \\
\hline & & $\%$ & 32.5 & 36.4 & 34.2 \\
\hline & severe & $\mathrm{n}$ & 14 & 27 & 41 \\
\hline & & $\%$ & 7.2 & 17.9 & 11.9 \\
\hline \multirow{2}{*}{\multicolumn{2}{|c|}{ Total }} & $\mathrm{n}$ & 194 & 151 & 345 \\
\hline & & $\%$ & 100.0 & 100.0 & 100.0 \\
\hline
\end{tabular}

Table 4 Association of caries status (age 18-44 years) and quality of life

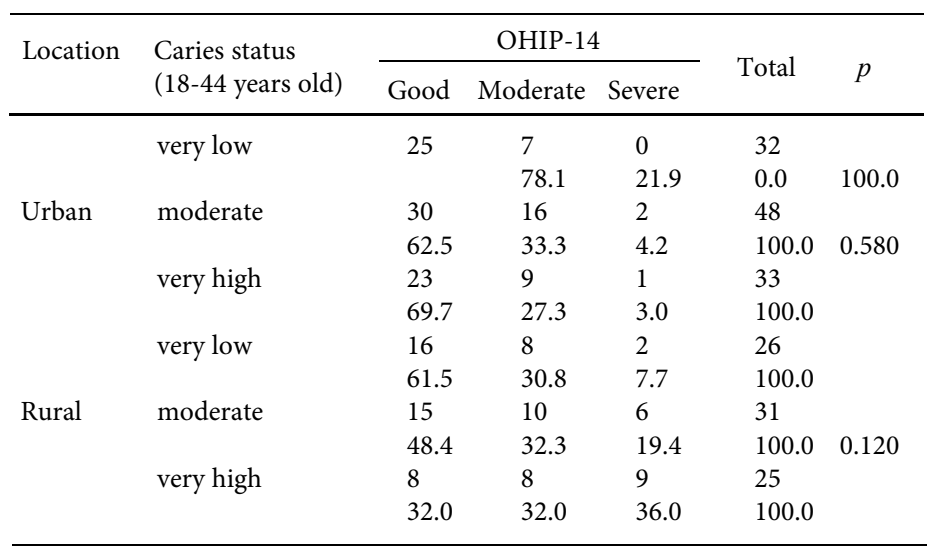

Table 5 Association of caries status (age $\geq 45$ years) and quality of life

\begin{tabular}{|c|c|c|c|c|c|c|c|}
\hline & \multirow{2}{*}{ Location } & & \multicolumn{3}{|c|}{ OHIP-14 } & \multirow{2}{*}{ Total } & \multirow{2}{*}{$p$} \\
\hline & & & Good & Moderate & Severe & & \\
\hline & very low & $\mathrm{n}$ & 15 & 17 & 1 & 33 & \\
\hline & & $\%$ & 45.5 & 51.5 & 3.0 & 100.0 & \\
\hline & low & $\mathrm{n}$ & 10 & 6 & 1 & 17 & \\
\hline & & $\%$ & 58.8 & 35.3 & 5.9 & 100.0 & \\
\hline \multirow[t]{8}{*}{ Urban } & moderate & $\mathrm{n}$ & 6 & 1 & 3 & 10 & $0.031^{*}$ \\
\hline & & $\%$ & 60.0 & 10.0 & 30.0 & 100.0 & \\
\hline & high & $\mathrm{n}$ & 8 & 7 & 6 & 21 & \\
\hline & & $\%$ & 38.1 & 33.3 & 28.6 & 100.0 & \\
\hline & very low & $\mathrm{n}$ & 11 & 12 & 3 & 26 & \\
\hline & & $\%$ & 42.3 & 46.2 & 11.5 & 100.0 & \\
\hline & low & $\mathrm{n}$ & 6 & 5 & 0 & 11 & \\
\hline & & $\%$ & 54.5 & 45.5 & 0.0 & 100.0 & \\
\hline \multirow[t]{4}{*}{ Rural } & moderate & $\mathrm{n}$ & 30 & 30 & 20 & 80 & 0.714 \\
\hline & & $\%$ & 37.5 & 37.5 & 25.0 & 100.0 & \\
\hline & high & $\mathrm{n}$ & 10 & 9 & 5 & 24 & \\
\hline & & $\%$ & 41.7 & 37.5 & 20.8 & 100.0 & \\
\hline
\end{tabular}

*Chi-square test; $\mathrm{p}<0.05$ significant

This study used pilot pathfinder design. The studysubjects comprised of 345,18 years of age andolder and were randomly selected from urban and rural areas in Pinrang Regency. The urban area refers to Watang Sawitto subdistrict and the rural area refers to Mattiro Bulu subdistrict and Suppa subdistrict. The inclusion criteria was adults with age 18 to 78 years old, subject cooperate and attend during the time of research.

\section{Oral examination}

All permanent teeth, excluding third molars, were taken into consideration to measure dental caries experience by the DMFT index recommended by the WHO, which is sum of decayed teeth (DT), missing teeth due to caries (MT), and filled teeth (FT).,10 For decay component when caries is recorded as present when a lesion in a pit or fissure, or an a smooth tooth surface, has an unmistakable cavity, undermined enamel or a detectably softened floor or wall. The CPI probe should be used to confirm visual evidence of caries on the tooth surface(s). Then, filling component is considered when a crown filled, without caries when one or more permanent restorations are present and there is no caries on the crown. ${ }^{10}$ Examination using mirror and Community Periodontal Index (CPI) probe, the classification of DMF-T index for young adult is very low $(0.0-1.1)$, low $(1.2-2.6)$, moderate (2.7-4.4), high (4.5-.6.5), very high $(>6.6)$, for adult and elderly was very low $(<5.0)$, low (5.0-8.9), moderate (9.0-13.9) and high (>13.9).

\section{Questionnaire survey}

The assessment of quality of life was carried out using Oral Health Impact Profile-14 (OHIP-14). It is based on locker's adaptation of the world health organization's classification of impairment, disabilities and handicaps. ${ }^{11}$ The OHIP questionnaire was developed in1994 (OHIP-49), and subsequently, a simplified version was developed in 1997, the OHIP-14, which assess the impact of oral health in different dimensions. ${ }^{10}$ OHIP-14 questionnaire includes seven dimensions with 14 items to determine the quality of life. The dimensions assessed by t'is instrument were functional limitations, physical pain, psychological discomfort, physical disability, psychological disability, social disability and handicap. ${ }^{1,5,6,11,13}$ The higher the average value of seven dimensions, the more negative the impact of oral health on quality of life. The OHIP-14 responses, "never", "hardly ever", "occasionally, "fairly often", and "very often", were codified from 0 to $4 .{ }^{3,5,11,13}$

The higher of the average value of seven dimensions, the more negative the impact of oral health on the quality of line of an individual. ${ }^{1,13}$ Classification of quality of life was made as good, moderate and severe. ${ }^{1}$ Range of scores from 0 to 56 . The category of good $=0-18$, moderate $=$ 19-37, severe $=38-56 .{ }^{13}$ In this study, OHIP-14 questionnaire that was simultaneously translated 
into Indonesia version.

\section{Statistical analysis}

The survey data were organized and analysed by using SPSS ver. 25 for Windows platform (SPSS Inc., Chicago, Illinois, USA). Chi-square analysis was used to explore the association between the variables. Differences were considered significant when $\mathrm{p}<0.05$.

\section{Results}

A total of 345 subjects (194 from urban dan 151 from rural) participated in the survey. Based on the characteristics of the age group, the category of young adults in the province was $56.5 \%$. Based on gender characteristics, the female category dominated for $73.6 \%$.

Table 1 shows the distribution of subjects based on sociodemographic characteristics and the mean values of DMFT and OHIP. In urban and rural areas, the DMFT value was highest in the elderly (60-78 years) with a good quality of life. The average value of component $\mathrm{F}$ in the adult community of Pinrang Regency was 0.00, which means no restoration was found. Based on the age category in urban areas, DMFT status was high at people $>60$ years of age. Based on gender, the DMF-T index in urban areas and rural areas was very high with a good quality of life.

The highest percentage was moderate caries status in urban areas is $42.5 \%$ and in rural areas is $37.8 \%$. Based on gender category in urban areas, male had the very low caries status $(41.2 \%)$ and most women had moderate caries status (46.8\%). In rural areas, based on gender, caries status was found equally i.e. moderate caries status.

In the 45-60 year category, caries status was at very low of $44.6 \%$ in urban areas and $38.6 \%$ in rural areas. In the age category of 60-78 years, caries status was at very high and high of $56.3 \%$ in urban areas and $52 \%$ in rural areas. Based on gender, 15 men in urban areas (55.6\%) had very low caries status while in rural areas 8 subjects $(44.4 \%)$ had high caries status. In women, very low caries status was found in urban and rural areas of 18 people $(33.3 \%)$ and 20 people $(39.2 \%)$, respectively.

Table 2 shows the distribution of quality of life based on the OHIP-14 questionnaire. On the functional limitations dimension, the highest percentage was from "never" response of $51.3 \%$ in difficult to speak questions and $42 \%$ in difficult to taste questions. In physical illness dimension, the highest percentage of choice answers was "sometimes" of $33 \%$ in severe pain questions and $31 \%$ in uncomfortable eating question. In psychological discomfort dimension, the highest percentage of choice answers was "sometimes" of $30.1 \%$ in anxious questions and "never" $38 \%$ tense question. In physical disability dimension, the highest percentage of choice answers was "sometimes" of $32.8 \%$ in not satisfied eating question and the choice of the answer "never" of $30.7 \%$ with disturbed by eating question.

In psychological incompetence dimension, the highest percentage of answer choices was "never", at $34.8 \%$ of restlessness question and $32.8 \%$ of shame question. In social limitations dimension, the highest percentage of answer choices was "never", of $38.6 \%$ in disturbed by others question and by $32.8 \%$ with difficult to work question. In handicap question, the highest percentage of answer choices was "never", of $36.8 \%$ with life less satisfying question and $34.2 \%$ in unable to function question.

Table 3 shows the distribution of subjects based on quality of life. The good quality of life category has the highest number of subjects with 186 (53.9\%) subjects. In the medium category there were 118 (34.2\%) subjects and the bad category had the least subjects with $47(11.9 \%)$ subjects.

Table 4 shows the relationship of caries status (age 18-44 years) on quality of life. In urban areas, the highest percentage is found in association of very low, moderate, and very high caries status with good quality of life. In rural areas, the highest percentage is in the association of very low and moderate caries status with good quality of life. Therefore, in the Chi-Square ttest in urban areas the p-value is 0.580 means that there was no significant association between caries status and the quality of life of the adult of the 18-44 year age category. In rural areas, the $p$ value was 0.120 means there is a relationship which was not significant between caries status and the quality of life of adult people in the 18-44 year age category.

Table 5 shows the association of caries status (age $\geq 45$ years) and quality of life. In urban areas, the highest percentage found in very low caries status is good quality of life (45.5\%) and in very high caries status found the highest percentage of poor quality of life (28.6\%). In the Chi-Square test, the $p$ value was 0.031 means that there was a significant association between caries status and the quality of life of the adult community in the age group $\geq 45$ years.

\section{Discussion}

The study result showed that no significant association between caries status and quality of life among young adult (18-44 years old) in urban and rural areas. This is in line with a research conducted by Abhisheket al. ${ }^{14}$ 
that no significant association between dental caries and quality of life scores among the police personnel. This is because, although they had high caries prevalence, probably the extent of caries was less severe, so the impact was less on their oral health-related quality of life.

On the other hand, the result on adult (45-60 years old) and elderly ( $>60$ years old) presented in this study, show a significant association between caries status and quality of life in urban area $(\mathrm{p}=0.031)$.

\section{Conclusion}

Monostotic fibrous dysplasia in this case was a benign tumor of the oral cavity with a low recurrence rate and preservation of the inferior alveolar nerve was performed with satisfactory results after 8 months. The inferior alveolar nerve preservation in this case was aimed at reducing complaints associated with paresthesia after hemimandibulectomy and bridging plate insertion was conducted.

\section{Acknowledgment}

The authors have received permission from the patients depicted in the manuscript to use their photographs for this purpose.

\section{Conflict of Interest}

The authors report no conflict of interest.

\section{References}

1. Husain FA, Tatengkeng F. Oral health-related quality of life appraised by OHIP-14 between urban and rural areas inKutaiKartanegara Regency, Indonesia: pilot pathfinder survey. Open Dent J 2017;11: 557-564.

2. Bennadi D, CVK Reddy. Oral health related quality of life. J Int Soc Prev Community Dent 2013;3: 1-6.

3. Agustina D, Hanindriyo L, Widita E, et al. The correlation between occurrence of dental caries and oral healthrelated quality of life (OHRQoL) of elderly population in Yogyakarta special region. J Med Sci 2018;50: 191-200.

4. Papaioannou W, Oulis CJ, Latsou D, et al. Oral healthrealated quality of life of greek adults: a cross-sectional study. Int J Dentistry 2011;1: 1-7.

5. Drachev SN, Brenn T, Trovik TA. Oral health-related quality of life in young adults: a survey of Russian undergraduate students. Int J Environ Res Public Health 2018;15: 1-13.

6. Sheng $\mathrm{X}$, Xiao $\mathrm{X}$, Song $\mathrm{X}$, et al. Correlation between oral health and quality of life among the elderly in Southwest China from 2013 to 2015. Med 2018:97: 1-7.
7. Soekanto SA, Fadillah F, Nuraisiya P, et al. The potentioal of several fluoride-based varnishes as remineralization agents: morphological studies, dentin surface hardness, and crystallinity tests. Int J Applied Pharm 2019;9: 60-66.

8. Faranitha R, Muhibat SS, Suyanti N. Perbedaan indeks DMF-T antara siswa SMP di perkotaandanperdesaanusia 12-13 tahun. J Ked Gi Unpad 2016;28: 176-184.

9. Badan Pusat Statistik. Kabupaten Pinrang dalam angka 2017. Badan Pusat Statistik Kabupaten Pinranng. ISSN: 2528-4312

10. Braga MM, Oliveira LB, Bonini GA, et al. Feasibility of the International Caries Detection and Assessment System (ICDAS-II) in epidemiologicalsurveys and comparability with standard World Health Organization criteria. Caries Res 2009;43: 245-249.

11. Gatten DL, Riedy CA, Hong SK, et al. Quality of life endodotically treated versus implat treated patients: a university-based qualitative research study. J Endo 2011:37: 903-909.

12. Xavier A, CarvalhoESd, BastosRdS, et al. Impact of dental caries on quality of life of Young adults according to access to oral health services: a cross sectional study. Braz J Oral Scl 2016;15: 1-7.

13. Anwar AI. Correlation between mental health and caries status in Primary School students. J Dentomaxillofac Sci 2018;3: 108-111.

14. Abhishek $\mathrm{KN}$, Shamarao S, Jain J, et al. Impact of caries prevalence on oral health-related quality of life among police personel in Virajpet, South India. J Int Soc Prev Community Dent 2014;4: 188-192.

15. SoaresJdSP, Santos LPdS, Cruz SSd, et al. The impact of caries in combination with periodontitis on oral health-related quality of life in Bahia, Brazil. J Perio 2018;89: 1407-1417.

16. Demirci $\mathrm{M}$, Ulu $\mathrm{T}$, Yildiz E, et al. Influence of age, sex and socioeconomic factors on dental health. Balk J Stoma 2009;13: 105-110.

17. Verenne B, Petersen PE, Ouattara S. Oral health status of children and adults in urban and rural areas of Bukina Faso, Africa. Int Dent J 2004;54: 83-89.

18. Palma PV, Caetano PL, Leite ICG. Impact of periodontal diseases on health-related quality of life of users of the Brazilian Unified Health System. Int J Dent 2013;1: 1-6.

19. Bastos RS, Carvalho ES, Xavier A, et al. Dental caries related to quality of life in two Brazilian adolescent group: a cross sectional study. Int Dent J 2012;62: 137-143.

20. Takeuchi MY, Ekuni D, Mizutani S, et al. Association among oral health-related quality of life, subjective symptoms, clinical status, and self-rated oral health in Japanese university students: a cross sectional study. BMC Oral Health 2016;16: 1-7.

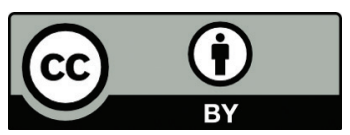

This work is licensed under a Creative Commons Attribution 